\title{
Identifikasi Prioritas Anak terhadap Indikator Kinerja Taman Bermain Layak Anak di Kota Surakarta
}

\author{
Nastiti Purnama Sari (1), Desiree Marlyn Kipuw (2) \\ (1) Mahasiswa, Program Studi Perencanaan Wilayah dan Kota, ITSB. nastitipurnamasari@gmail.com \\ (2) Staf Pengajar, Program Studi Perencanaan Wilayah dan Kota, ITSB. desiree.marlynkipuw@gmail.com
}

\begin{abstract}
Abstrak
Melalui kebijakan Kabupaten/Kota Layak Anak, pemenuhan hak bermain anak diharapkan dapat terwujud, salah satunya dengan menyediakan taman bermain yang layak anak. Kota Surakarta terpilih sebagai salah satu model pengembangan Kabupaten/Kota Layak Anak di Indonesia pada tahun 2006. Dukungan pemerintah Kota Surakarta dalam pemenuhan hak bermain anak dibuktikan dengan membangun Taman Anak Cerdas sebagai tempat bermain, belajar, dan berkreativitas. Selain dukungan pemerintah, dalam mewujudkan Taman Anak Cerdas sebagai tempat bermain anak, juga membutuhkan dukungan masyarakat, termasuk anak-anak, sebagai pengguna fasilitas Taman Bermain. Penelitian ini bertujuan untuk menentukan prioritas indikator kinerja taman bermain layak anak berdasarkan persepsi anak di Kota Surakarta. Teknik pengumpulan data dilakukan melalui studi dokumentasi, wawancara, observasi, dan kuesioner. Teknik pengambilan sampel menggunakan metode accidental sampling. Adapun teknik analisis data dilakukan dengan metode statistik deskriptif. Hasil penelitian menunjukkan bahwa taman bermain dengan fasilitas beragam; lingkungan aman, bersih, dan sehat; serta lokasi taman yang terjangkau menjadi prioritas teratas bagi anak.
\end{abstract}

Kata-kunci: indikator kinerja prioritas, Kabupaten/Kota Layak Anak, persepsi anak, Taman Anak Cerdas, taman bermain layak anak

\begin{abstract}
Through the Child Friendly City/Regency policy, it is expected that the fulfilment of children's play rights can be achieved, one of them is by providing playgrounds that are suitable for children. Surakarta City was chosen as one of the models for the development of Child Friendly Cities in Indonesia in 2006. The support from the Surakarta City Government in fulfilling children's play rights is evidenced by building a Smart Children's Park as a place to play, learn, and be creative. In addition to government support, to make this happen, it must also be supported by the community, including children as the users of the facility. This study aims to determine the priority indicators of children's playground performance based on children's perceptions in the city of Surakarta. Data collection techniques were carried out through the study of documentation, interviews, observations, and questionnaires. The sampling technique is using accidental sampling. While the data analysis technique is using descriptive statistics technique. The results showed that the playground with various facilities; safe, clean and healthy environment; and affordable park locations are the top priority indicators for children.
\end{abstract}

Keywords: performance based priority indicators, Child Friendly Cities, child perception, Smart Children's Park, child friendly playground

\section{PENGANTAR}

Anak merupakan kelompok penduduk usia muda yang memiliki potensi dan perlu disiapkan untuk dikembangkan agar dapat berpartisipasi aktif dalam pembangunan di masa mendatang. Anak juga merupakan makhluk bermain dan sudah seharusnya memperoleh pelayanan fasilitas kota berupa taman bermain (Joga dan Antar, 2007:187). Selain membawa keriangan, kesenangan, dan kegembiraan bagi anak, bermain juga memiliki manfaat yang baik untuk 
anak, seperti dapat mengembangkan daya cipta, imajinasi, dan kreativitas anak serta dapat pula mengembangkan kemampuan kognitif, sosial, fisik, dan emosional anak (Sari, 2011). Oleh karena itu, dalam suatu lingkungan sangat dibutuhkan untuk menyediakan sebuah tempat bermain bagi anak. Sari (2011) menjelaskan bahwa anak memiliki mobilitas yang masih terbatas dan akan sangat tergantung dengan lingkungan tempat bermukimnya untuk memenuhi segala kebutuhannya, termasuk kebutuhan akan lingkungan bermain. Jika lingkungannya tidak memiliki tempat bermain, dikuatirkan anak akan bermain di tempat yang berisiko tinggi, seperti di jalan.

Dewasa ini, Indonesia dan negara-negara di dunia telah sepakat dalam memenuhi hak-hak anak, termasuk hak bermain anak, melalui sebuah kebijakan Child Friendly City atau Kabupaten/Kota Layak Anak. Kebijakan ini diartikan oleh United Nations Children's Fund (UNICEF) sebagai sebuah kota yang menjamin pemenuhan hak anak sebagai warga kota, termasuk hak bermain anak. Adapun upaya Pemerintah Indonesia dalam menanggapi hal tersebut adalah dengan menetapkan 31 (tiga puluh satu) indikator Kabupaten/Kota Layak Anak melalui Peraturan Menteri Negara Pemberdayaan Perempuan Nomor 12 Tahun 2011 tentang Indikator Kabupaten/Kota Layak Anak. Ketigapuluh satu indikator tersebut dikelompokkan menjadi 6 (enam) bagian dan 5 (lima) klaster. Taman bermain termasuk ke dalam klaster pendidikan, pemanfaatan waktu luang, dan kegiatan budaya, dengan salah satu indikator yang berkaitan adalah penyediaan fasilitas bermain dan rekreasi serta sarana kreativitas anak.

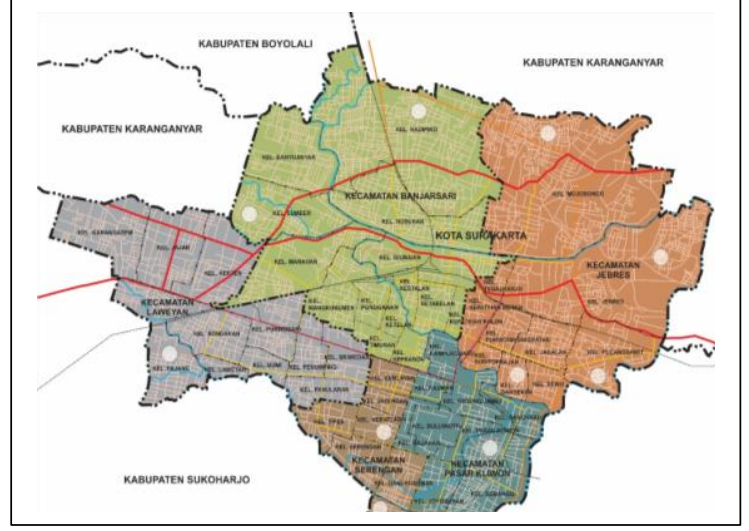

Gambar 1. Sebaran Taman Anak Cerdas di Kota Surakarta, Tahun 2018

Pada tahun 2017, Kota Surakarta telah dinobatkan sebagai Kota Menuju Layak Anak dengan kategori tertinggi kedua, yakni Utama (Pramudya, 2017). Hal ini menunjukkan bahwa penerapan kebijakan Kabupaten/Kota Layak Anak di Kota Surakarta dianggap telah cukup memberi dampak bagi penduduk usia anakanak. Adapun salah satu dukungan Pemerintah Kota Surakarta dalam memenuhi hak bermain anak tersebut dilakukan dengan membangun Taman Anak Cerdas di 10 (sepuluh) kelurahan sebagai tempat anak untuk bermain, belajar, dan berkreativitas. Pembangunan taman tersebut juga merupakan salah satu program Kota Surakarta Menuju Layak Anak. Untuk menunjukkan keseriusannya, Pemerintah Kota Surakarta juga telah mengeluarkan Peraturan Walikota Surakarta Nomor 6 Tahun 2008 tentang Petunjuk Pelaksanaan Taman Anak Cerdas (TAC) Kota Surakarta. Akan tetapi, berdasarkan hasil penelitian Utami (2014:10-11) disebutkan bahwa belum semua Taman Anak Cerdas yang terdapat di Kota Surakarta, berfungsi secara optimal untuk memenuhi kebutuhan dan hak anak disebabkan kondisi fasilitas yang tersedia belum dapat digunakan secara optimal oleh anak.

Merujuk pada pendapat United Nations Children's Fund (UNICEF) (2004:2), bahwa dalam mewujudkan Kabupaten/Kota Layak Anak, termasuk taman bermain layak anak, tidak dapat dicapai hanya oleh pemerintah sendiri, akan tetapi juga harus didukung dengan kerjasama dari masyarakat, termasuk anak sebagai pengguna. Adams dan Ingham (1998) dalam Patilima, dkk (2014:12) juga menekankan bahwa anak, seperti halnya orang dewasa, dapat 
diajak kerjasama dalam mengatasi persoalan yang berhubungan dengan lingkungan kota. Oleh karena itu, sudah selayaknya partisipasi dari anak diperlukan agar keberadaan taman bermain dapat sesuai dengan kebutuhan sekaligus keinginan anak sebagai penggunanya.

Di samping itu, Indonesia belum memiliki indikator yang secara khusus digunakan untuk membangun serta mengukur kinerja taman bermain sebagai pendukung Kabupaten/Kota Layak Anak menyebabkan setiap wilayah perlu merumuskan indikator tersendiri sesuai kebutuhannya masing-masing. Adapun dalam pedoman pembangunan Taman Anak Cerdas yang merupakan taman bermain layak anak di Kota Surakarta, secara keseluruhan hanya menyebutkan hal-hal yang bersifat umum saja.

Berdasarkan hal tersebut, penelitian ini bertujuan untuk merumuskan secara khusus indikator kinerja taman bermain layak anak berdasarkan persepsi anak. Kajian ini dimulai dengan terlebih dahulu mengumpulkan 'daftar panjang' indikator Kabupaten/Kota Layak Anak dan indikator kinerja taman bermain dari berbagai sumber kemudian menggabungkan dan mereduksinya untuk menghasilkan indikator kinerja taman bermain layak anak berdasarkan berbagai literatur dan kebijakan. Indikator kinerja tersebut dapat diartikan sebagai acuan dalam menilai kinerja taman bermain yang layak anak, sekaligus dapat dijadikan pedoman dalam perencanaan dan pembangunan taman bermain layak anak agar dapat berfungsi secara optimal.

Pada tahapan selanjutnya, penelitian ini melibatkan anak-anak sebagai pengguna taman bermain untuk berpartisipasi dalam menentukan prioritas indikator kinerja taman bermain tersebut berdasarkan persepsi anak. Hasil penelitian ini diharapkan dapat menjadi masukan dalam pengembangan Taman Anak Cerdas di Kota Surakarta secara khusus, di samping peraturan terkait yang telah ada, serta dapat pula menjadi masukan bagi pengembangan taman bermain layak anak di kota-kota lain di Indonesia.

\section{METODE}

Penelitian ini menggunakan metode deskriptif dengan pendekatan kuantitatif. Sementara teknik pengumpulan data berupa studi dokumentasi, wawancara, observasi, dan kuesioner. Responden pada penelitian ini adalah anak usia 9-12 tahun yang dipilih menggunakan metode accidental sampling. Adapun teknik analisis datanya adalah analisis statistik deskriptif. Tahapan analisis pada penelitian ini sebagai berikut:

a. Tahap pertama, menetapkan responden yang terlibat, yaitu anak usia 9-12 tahun yang sedang berkunjung di Taman Anak Cerdas Kota Surakarata.

b. Tahap kedua, menentukan indikator kinerja taman bermain layak anak berdasarkan literatur yang akan digunakan sebagai data awal untuk responden dalam memprioritaskan indikator kinerja tersebut. Indikator ini didapat dari hasil kajian mengenai Kabupaten/Kota Layak Anak dan taman bermain.

c. Tahap ketiga, dilakukan pengumpulan data di lapangan dengan penyebaran kuesioner kepada responden. Responden diminta untuk mengurutkan 10 (sepuluh) indikator kinerja taman bermain layak anak berdasarkan literatur dari yang sangat diinginkan (1) hingga tidak diinginkan (10) dalam penyediaan taman bermain.

d. Tahap keempat, mengidentifikasi prioritas terhadap indikator kinerja taman bermain layak anak berdasarkan persepsi anak. Pada tahap ini dilakukan pengolahan data hasil kuesioner dengan teknik analisis statistik deskriptif. Penelitian ini menggunakan data peringkat dalam analisis. Hal ini menunjukkan dalam menganalisis data tersebut, setiap pilihan responden menunjukkan letak nilai. Hal ini memiliki konsekuensi bahwa setiap pilihan pada jawaban menunjukkan nilai tertentu. Dengan demikian, Arikunto (2013:285) menjabarkan analisis datanya sebagai berikut.

- Langkah 1: melakukan tabulasi data dengan metode tally untuk mengetahui frekuensi setiap peringkat indikator kinerja pilihan responden.

- Langkah 2: frekuensi pada masingmasing peringkat indikator kinerja dikalikan dengan nilai peringkatnya 
sehingga diperoleh nilai untuk setiap peringkat.

- Langkah 3: nilai peringkat tersebut dijumlahkan dan diperoleh nilai untuk setiap indikator kinerja.

- Langkah 4: nilai indikator kinerja dibagi dengan banyaknya responden sehingga menghasilkan nilai rata-rata.

- Langkah 5: untuk mengetahui peringkat akhir, nilai pada kolom 4 diurutkan dari yang terkecil hingga terbesar.

\section{DISKUSI}

Penelitian ini merumuskan 10 (sepuluh) indikator kinerja serta 33 (tiga puluh tiga) ukuran indikator kinerja taman bermain layak anak berdasarkan literatur (Lihat Tabel 1). Perumusan indikator kinerja tersebut diperoleh dari proses penggabungan dan reduksi terhadap 95 indikator serta 177 (seratus tujuh puluh tujuh) ukuran indikator Kabupaten/Kota Layak Anak dari berbagai sumber ditambah 35 indikator kinerja serta 126 (seratus dua puluh enam) ukuran indikator kinerja taman bermain dari berbagai sumber. Indikator kinerja tersebut selanjutnya dibandingkan dengan pedoman pembangunan Taman Anak Cerdas sebagai taman bermain layak anak di Kota Surakarta yang merupakan Peraturan Walikota Surakarta Nomor 6 Tahun 2008 tentang Petunjuk Pelaksanaan Taman Anak Cerdas (TAC) Kota Surakarta. Dari perbandingan tersebut, dapat terlihat bahwa secara keseluruhan, indikator kinerja tersebut belum seluruhnya terdapat dalam peraturan/ pedoman (Lihat Tabel 2). Dengan demikian, diharapkan indikator kinerja taman bermain layak anak pada studi ini, yang diperoleh lewat berbagai literatur ini, dapat digunakan sebagai pendukung atau pelengkap peraturan dalam pembangunan Taman Anak Cerdas di Kota Surakarta, secara khusus, ataupun untuk. pengembangan taman bermain layak anak di kota-kota lain di Indonesiaelanjutnya, indikator kinerja taman bermain layak anak pada tabel 1 . di atas, yang kemudian dijadikan dasar dalam kuesioner untuk memperoleh indikator kinerja prioritas taman cerdas layak anak berdasarkan presepsi anak pengguna Taman Anak Cerdas di Kota Surakarta. Adapun responden anak pada penelitian ini sebanyak 46 (empat puluh enam) anak yang tersebar di seluruh taman cerdas yang ada di Kota Surakarta. Untuk mengetahui rekapitulasi data hasil kuesioner tersebut, dapat dilihat pada Tabel 3.

Data hasil kuesioner tersebut diolah menggunakan statistik deskriptif guna mengetahui prioritas indikator kinerja TCA menurut anak. Pada tabel 4. di bawah, menunjukkan hasil pengolahan data indikator kinerja prioritas berdasarkan persepsi anak pada penelitian ini. 
Tabel 1. Indikator Kinerja Taman Bermain Layak Anak Berdasarkan Literatur

\begin{tabular}{|c|c|c|c|}
\hline No. & Indikator Kinerja & Ukuran Indikator Kinerja & Sumber \\
\hline \multirow{2}{*}{1} & \multirow{2}{*}{$\begin{array}{l}\text { Lokasi tama dapat } \\
\text { ditempuh dengan } \\
\text { berjalan kaki atau } \\
\text { bersepeda }\end{array}$} & Lokasi taman berjarak $\leq 200$ meter dari rumah & $\begin{array}{l}\text { Moore, } 1992 \text { dalam Dewi, } \\
\text { 2012; Goose, } 2014\end{array}$ \\
\hline & & $\begin{array}{l}\text { Tersedianya jalur pejalan kaki atau sepeda di } \\
\text { sekitar taman }\end{array}$ & $\begin{array}{l}\text { Moore, } 1992 \text { dalam Dewi, } \\
\text { 2012; Sari, dkk, } 2017\end{array}$ \\
\hline \multirow{4}{*}{2} & \multirow{4}{*}{$\begin{array}{l}\text { Menjadikan taman } \\
\text { sebagai lingkungan } \\
\text { yang aman untuk anak } \\
\text { bermain }\end{array}$} & $\begin{array}{l}\text { Tidak terletak di dekat sungai/selokan } \\
\text { besar/jalan raya untuk menghindari anak dari } \\
\text { bahaya terjatuh dan tertabrak }\end{array}$ & $\begin{array}{l}\text { Moore, } 1992 \text { dalam Dewi, } \\
2012\end{array}$ \\
\hline & & $\begin{array}{l}\text { Tersedianya polisi tidur di dekat taman yang } \\
\text { membuat kendaraan yang melintas menjadi } \\
\text { lebih lambat }\end{array}$ & Goose, 2014 \\
\hline & & $\begin{array}{l}\text { Menutup drainase/selokan yang terbuka di } \\
\text { sekitar taman untuk menghindari anak terjatuh } \\
\text { ke dalamnya }\end{array}$ & $\begin{array}{l}\text { Bartlett, } 2005 \text { dalam } \\
\text { Woolcock dan Steele, } \\
2008\end{array}$ \\
\hline & & $\begin{array}{l}\text { Taman bermain dilindungi oleh dinding/pagar/ } \\
\text { penghalang sebagai pembatas taman dengan } \\
\text { ketinggian }<150 \mathrm{~cm}\end{array}$ & $\begin{array}{l}\text { Moore, } 1992 \text { dalam Dewi, } \\
2012\end{array}$ \\
\hline \multirow{5}{*}{3} & \multirow{5}{*}{$\begin{array}{l}\text { Menjadikan taman } \\
\text { sebagai lingkungan } \\
\text { yang bersih dan sehat }\end{array}$} & $\begin{array}{l}\text { Tempat bagi anak bermain bebas dari sampah } \\
\text { dan limbah }\end{array}$ & \multirow{2}{*}{$\begin{array}{l}\text { Bartlett, } 2005 \text { dalam } \\
\text { Woolcock dan Steele, } \\
2008\end{array}$} \\
\hline & & $\begin{array}{l}\text { Tersedianya kamar mandi yang bersih dan tidak } \\
\text { bau }\end{array}$ & \\
\hline & & Tersedianya tempat sampah & Sari, dkk, 2017 \\
\hline & & Merupakan kawasan tanpa rokok & $\begin{array}{l}\text { Kementerian } \\
\text { Pemberdayaan } \\
\text { Perempuan dan } \\
\text { Perlindungan Anak, 2011; } \\
\text { Dinas PPPA, dan } \\
\text { Pemberdayaan } \\
\text { Masyarakat Kota } \\
\text { Surakarta }\end{array}$ \\
\hline & & $\begin{array}{l}\text { Tersedianya ruang hijau yang menyejukkan dan } \\
\text { bermanfaat untuk menciptakan lingkungan yang } \\
\text { sehat }\end{array}$ & Goose, 2014 \\
\hline 4 & $\begin{array}{l}\text { Adanya nilai daya tarik } \\
\text { dan keindahan taman } \\
\text { bermain sehingga } \\
\text { pengunjung merasa } \\
\text { nyaman secara visual }\end{array}$ & $\begin{array}{l}\text { Penetapan lokasi taman bermain } \\
\text { memperhatikan keindahan lingkungan sekitar } \\
\text { sehingga pada titik tertentu pengunjung dapat } \\
\text { menikmati pemandangan yang indah di dalam } \\
\text { dan di luar taman }\end{array}$ & \multirow{4}{*}{ Baskara, 2011} \\
\hline \multirow{4}{*}{5} & \multirow{4}{*}{$\begin{array}{l}\text { Adanya pengaturan } \\
\text { dalam tata letak taman } \\
\text { bermain }\end{array}$} & $\begin{array}{l}\text { Tata letak taman bermain didasari zonasi } \\
\text { aktivitas bermain aktif-pasif, kelompok umur, dan } \\
\text { jenis permainan }\end{array}$ & \\
\hline & & $\begin{array}{l}\text { Peletakan fasilitas permainan didasari } \\
\text { pergerakan dan meminimalkan terjadi benturan } \\
\text { antar anak maupun anak dengan peralatan } \\
\text { permainan yang bergerak (misal ayunan, } \\
\text { jungkat-jungkit, dan lainnya) }\end{array}$ & \\
\hline & & $\begin{array}{l}\text { Tata letak didukung dengan sarana sirkulasi } \\
\text { yang mudah dilalui }\end{array}$ & \\
\hline & & $\begin{array}{l}\text { Adanya pemisahan area taman, seperti } \\
\text { menggunakan pohon dan pagar agar tidak saling } \\
\text { terganggu antar kegiatan bermain }\end{array}$ & $\begin{array}{l}\text { Goosen, 2014; Baskara, } \\
2011\end{array}$ \\
\hline
\end{tabular}




\begin{tabular}{|c|c|c|c|}
\hline No. & Indikator Kinerja & Ukuran Indikator Kinerja & Sumber \\
\hline 6 & $\begin{array}{l}\text { Adanya keterlibatan } \\
\text { anak dalam } \\
\text { pembangunan taman } \\
\text { bermain }\end{array}$ & $\begin{array}{l}\text { Tersedianya forum sebagai tempat berdiskusi dan } \\
\text { berkonsultasi dengan anak dalam pengambilan } \\
\text { keputusan tentang pengembangan taman } \\
\text { bermain, seperti jenis permainan }\end{array}$ & $\begin{array}{l}\text { Kementerian } \\
\text { Pemberdayaan } \\
\text { Perempuan dan } \\
\text { Perlindungan Anak, } \\
\text { 2011; Sari, dkk, } 2017\end{array}$ \\
\hline \multirow{4}{*}{7} & \multirow{4}{*}{$\begin{array}{l}\text { Tersedianya fasilitas } \\
\text { bermain, dengan } \\
\text { minimal satu } \\
\text { perlengkapan } \\
\text { permainan, yang } \\
\text { aman dan tidak } \\
\text { memungkinkan } \\
\text { terjadinya kecelakaan } \\
\text { bagi anak }\end{array}$} & $\begin{array}{l}\text { Area alas/di bawah peralatan permainan harus } \\
\text { dengan bahan yang mampu meminimalkan } \\
\text { benturan saat anak terjatuh dari peralatan } \\
\text { permainan }\end{array}$ & \multirow{4}{*}{ Baskara, 2011} \\
\hline & & $\begin{array}{l}\text { Bahan yang bersentuhan langsung dengan kulit } \\
\text { anak memiliki tingkat tekstur yang halus }\end{array}$ & \\
\hline & & Bahan pegangan tangan tidak bersifat licin & \\
\hline & & $\begin{array}{l}\text { Bahan pijakan harus meminimalisasikan terjadinya } \\
\text { slip }\end{array}$ & \\
\hline \multirow[b]{3}{*}{8} & \multirow[b]{3}{*}{$\begin{array}{l}\text { Tersedianya fasilitas } \\
\text { selain untuk bermain } \\
\text { yang dapat digunakan, } \\
\text { dimengerti, dan } \\
\text { dijangkau oleh semua } \\
\text { anak }\end{array}$} & $\begin{array}{l}\text { Tersedianya fasilitas belajar, seperti ruang } \\
\text { perpustakaan dan ruang komputer }\end{array}$ & \multirow{2}{*}{ Sari, dkk, 2017} \\
\hline & & $\begin{array}{l}\text { Tersedianya fasilitas olah raga, seperti lapangan } \\
\text { olah raga }\end{array}$ & \\
\hline & & $\begin{array}{l}\text { Tersedianya fasilitas kreativitas anak, seperti } \\
\text { panggung seni kreativitas/pengembangan bakat } \\
\text { atau area pertunjukan }\end{array}$ & $\begin{array}{l}\text { Sari, dkk, 2017; } \\
\text { Kementerian } \\
\text { Pemberdayaan } \\
\text { Perempuan dan } \\
\text { Perlindungan Anak, } \\
\text { 2011; Dinas } \\
\text { Pemberdayaan } \\
\text { Perempuan, } \\
\text { Perlindungan Anak, dan } \\
\text { Pemberdayaan } \\
\text { Masyarakat Kota } \\
\text { Surakarta }\end{array}$ \\
\hline \multirow{4}{*}{9} & \multirow{4}{*}{$\begin{array}{l}\text { Tesedianya fasilitas } \\
\text { dan desain taman bagi } \\
\text { penyandang } \\
\text { disabilitas agar lebih } \\
\text { mudah untuk bergerak }\end{array}$} & Tersedianya ramp & \multirow{4}{*}{$\begin{array}{l}\text { Bartlett, } 2005 \text { dalam } \\
\text { Woolcock dan Steele, } \\
2008\end{array}$} \\
\hline & & Tersedianya jalur untuk tuna netra & \\
\hline & & Tersedianya perosotan yang dibuat landau & \\
\hline & & $\begin{array}{l}\text { Tersedianya ayunan yang dapat memuat kursi } \\
\text { roda }\end{array}$ & \\
\hline \multirow{3}{*}{10} & \multirow{3}{*}{$\begin{array}{l}\text { Tersedianya fasilitas } \\
\text { umum di dalam } \\
\text { maupun sekitar taman }\end{array}$} & Terdapat warung di sekitar taman bermain & Sari, dkk, 2017 \\
\hline & & $\begin{array}{l}\text { Terdapat area untuk duduk sebagai tempat anak } \\
\text { untuk beristirahat maupun untuk orang tua yang } \\
\text { sedang menunggui anaknya bermain }\end{array}$ & $\begin{array}{l}\text { Goose, 2014; Sari, dkk, } \\
2017\end{array}$ \\
\hline & & $\begin{array}{l}\text { Tersedianya parkir khusus untuk sepeda, motor, } \\
\text { dan mobil bagi pengunjung taman yang membawa } \\
\text { kendaraan }\end{array}$ & Sari, dkk, 2017 \\
\hline
\end{tabular}

Sumber: Hasil Pengolahan, 2018 
Tabel 2. Perbandingan Indikator Kinerja Taman Bermain Layak Anak Berdasarkan Literatur dengan Peraturan

\begin{tabular}{|c|c|c|}
\hline No. & Indikator Kinerja & Peraturan Walikota Terkait \\
\hline 1 & $\begin{array}{l}\text { Tersedianya fasilitas selain untuk } \\
\text { bermain yang dapat digunakan, } \\
\text { dimengerti, dan dijangkau oleh semua } \\
\text { anak }\end{array}$ & $\begin{array}{l}\text { Di dalam peraturan disebutkan bahwa, fasilitas minimal yang } \\
\text { harus tersedia di Taman Anak Cerdas, meliputi ruang } \\
\text { perpustakaan, komputer, olah raga, bermain, serta kreativitas }\end{array}$ \\
\hline 2 & $\begin{array}{l}\text { Lokasi taman dapat ditempuh dengan } \\
\text { berjalan kaki atau bersepeda }\end{array}$ & \multirow{5}{*}{$\begin{array}{l}\text { Terdapat beberapa pernyataan tersirat di dalam peraturan dan } \\
\text { tidak dijelaskan secara rinci, sebagai berikut. } \\
\text { - Hanya disebutkan lokasi pembangunan Taman Anak } \\
\text { Cerdas harus berada di lokasi yang strategis dan tidak } \\
\text { dijelaskan secara lebih lanjut } \\
\text { - Salah satu tujuan pembangunan Taman Anak Cerdas } \\
\text { adalah menyediakan tempat bermain yang nyaman dan } \\
\text { aman untuk anak. Namun, tidak dijelaskan secara lebih } \\
\text { lanjut fasilitas dan desain taman yang seperti apa untuk } \\
\text { memenuhi tujuan tersebut } \\
\text { - Fasilitas bermain menjadi fasilitas minimal yang harus } \\
\text { tersedia di Taman Anak Cerdas, namun penyediaannya } \\
\text { tidak diatur secara detail di dalam peraturan } \\
\text { - Hanya menyebutkan bahwa dalam kepengurusan Taman } \\
\text { Anak Cerdas perlu adanya petugas pengelola kebersihan } \\
\text { yang memiliki tanggung jawab terhadap kebersihan taman. } \\
\text { Namun, tidak disebutkan bahwa perlu menciptakan Taman } \\
\text { Anak Cerdas sebagai lingkungan yang sehat } \\
\text { - Salah satu asas dalam membangun Taman Anak Cerdas } \\
\text { adalah non diskriminasi. Namun, tidak dijelaskan secara } \\
\text { lebih lanjut fasilitas dan desain taman yang seperti apa untuk } \\
\text { memenuhi asas non diskriminasi }\end{array}$} \\
\hline 3 & $\begin{array}{l}\text { Menjadikan taman sebagai lingkungan } \\
\text { yang aman untuk anak bermain }\end{array}$ & \\
\hline 4 & $\begin{array}{l}\text { Tersedianya fasilitas bermain, dengan } \\
\text { minimal satu perlengkapan } \\
\text { permainan, yang aman dan tidak } \\
\text { memungkinkan terjadinya kecelakaan } \\
\text { bagi anak }\end{array}$ & \\
\hline 5 & $\begin{array}{l}\text { Menjadikan taman sebagai lingkungan } \\
\text { yang bersih dan sehat }\end{array}$ & \\
\hline 6 & $\begin{array}{l}\text { agi penyandang disabilitas } \\
\text { h mudah untuk bergerak }\end{array}$ & \\
\hline 7 & $\begin{array}{l}\text { nilai daya tarik dan keindahan } \\
\text { ermain sehingga pengunjung } \\
\text { yyaman secara visual }\end{array}$ & \multirow{4}{*}{$\begin{array}{l}\text { Tidak disebutkan di dalam peraturan bahwa: } \\
\text { - Perlu menciptakan Taman Anak Cerdas yang memiliki daya } \\
\text { tarik dan keindahan } \\
\text { - Perlu adanya pengaturan dalam tata letak Taman Anak } \\
\text { Cerdas } \\
\text { - Perlu menyediakan fasilitas umum di dalam maupun di } \\
\text { sekitar Taman Anak Cerdas } \\
\text { - Perlu melibatkan anak dalam pembangunan Taman Anak } \\
\text { Cerdas }\end{array}$} \\
\hline 8 & $\begin{array}{l}\text { Adanya pengaturan dalam tata letak } \\
\text { taman bermain }\end{array}$ & \\
\hline 9 & $\begin{array}{l}\text { Tersedianya fasilitas umum di dalam } \\
\text { maupun sekitar taman }\end{array}$ & \\
\hline 10 & $\begin{array}{l}\text { Adanya keterlibatan anak dalam } \\
\text { pembangunan taman bermain }\end{array}$ & \\
\hline
\end{tabular}

Sumber: Hasil Pengolahan, 2018

Tabel 3. Rekapitulasi Data Hasil Kuesioner

\begin{tabular}{|c|c|c|c|c|c|c|c|c|c|c|}
\hline \multirow{2}{*}{$\begin{array}{c}\text { Indikator } \\
\text { Kinerja }\end{array}$} & \multicolumn{10}{|c|}{ Frekuensi Per Peringkat Indikator Kinerja } \\
\hline & P.1 & P.2 & P.3 & P.4 & P.5 & P.6 & P.7 & P.8 & P.9 & P.10 \\
\hline 1.1 & 12 & 4 & 6 & 2 & 6 & 3 & 1 & 1 & 7 & 4 \\
\hline 1.2 & 5 & 10 & 4 & 7 & 4 & 5 & 2 & 4 & 1 & 4 \\
\hline 1.3 & 7 & 15 & 8 & 5 & 1 & 1 & 3 & 3 & 2 & 1 \\
\hline 1.4 & 3 & 3 & 1 & 2 & 6 & 6 & 2 & 13 & 8 & 2 \\
\hline 1.5 & 1 & 3 & 2 & 3 & 2 & 6 & 10 & 8 & 7 & 4 \\
\hline 1.6 & 2 & 1 & 3 & 1 & 0 & 1 & 5 & 4 & 8 & 21 \\
\hline 1.7 & 5 & 6 & 10 & 12 & 5 & 2 & 1 & 1 & 3 & 1 \\
\hline 1.8 & 10 & 2 & 7 & 9 & 10 & 2 & 3 & 1 & 2 & 0 \\
\hline 1.9 & 1 & 0 & 3 & 3 & 9 & 14 & 7 & 3 & 3 & 3 \\
\hline I.10 & 0 & 2 & 2 & 2 & 3 & 6 & 12 & 8 & 5 & 6 \\
\hline
\end{tabular}

Sumber: Hasil Pengolahan, 2018

Keterangan: I.n = Indikator ke-n; P.n = Peringkat ke-n 
Tabel 4. Pengolahan Data Hasil Kuesioner

\begin{tabular}{crrrrrrrrrrrrrr}
\hline $\begin{array}{c}\text { Indikator } \\
\text { Kinerja }\end{array}$ & \multicolumn{1}{c}{ P.1 } & P.2 & P.3 & P.4 & P.5 & P.6 & P.7 & P.8 & P.9 & P.10 & $\begin{array}{c}\text { Nilai } \\
\text { Indikator } \\
\text { Kinerja }\end{array}$ & $\begin{array}{c}\text { Rata- } \\
\text { Rata }\end{array}$ & $\begin{array}{c}\text { Peringkat } \\
\text { Akhir }\end{array}$ \\
\hline I.1 & 12 & 8 & 18 & 8 & 30 & 18 & 7 & 8 & 63 & 40 & 212 & 4,61 & \\
\hline I.2 & 5 & 20 & 12 & 28 & 20 & 30 & 14 & 32 & 9 & 40 & 210 & 4,57 & 5 \\
\hline I.3 & 7 & 30 & 24 & 20 & 5 & 6 & 21 & 24 & 18 & 10 & 165 & 3,59 & 4 \\
\hline I.4 & 3 & 6 & 3 & 8 & 30 & 36 & 14 & 104 & 72 & 20 & 296 & 6,43 & 1 \\
\hline I.5 & 1 & 6 & 6 & 12 & 10 & 36 & 70 & 64 & 63 & 40 & 308 & 6,70 & 7 \\
\hline I.6 & 2 & 2 & 9 & 4 & 0 & 6 & 35 & 32 & 72 & 210 & 372 & 8,09 & 8 \\
\hline I.7 & 5 & 12 & 30 & 48 & 25 & 12 & 7 & 8 & 27 & 10 & 184 & 4,00 & 10 \\
\hline I.8 & 10 & 4 & 21 & 36 & 50 & 12 & 21 & 8 & 18 & 0 & 180 & 3,91 & 3 \\
\hline I.9 & 1 & 0 & 9 & 12 & 45 & 84 & 49 & 24 & 27 & 30 & 281 & 6,11 & 2 \\
\hline I.10 & 0 & 4 & 6 & 8 & 15 & 36 & 84 & 64 & 45 & 60 & 322 & 7,00 & 6 \\
\hline
\end{tabular}

Sumber: Hasil Pengolahan, 2018

Keterangan: I. $n=$ Indikator ke-n

P. $n=$ Peringkat ke-n

Berdasarkan hasil pengolahan data kuesioner tersebut, dapat diketahui prioritas setiap indikator kinerja menurut anak dengan melihat urutan peringkat setiap indikator (Lihat Tabel $5)$.

Tabel 5. Indikator Kinerja Prioritas Taman Bermain Layak Anak Berdasarkan Persepsi Anak

\begin{tabular}{cl}
\hline No. & \multicolumn{1}{c}{ Indikator Kinerja } \\
\hline 1 & $\begin{array}{l}\text { Menjadikan taman sebagai lingkungan yang } \\
\text { bersih dan sehat }\end{array}$ \\
\hline 2 & $\begin{array}{l}\text { Tersedianya fasilitas selain untuk bermain } \\
\text { yang dapat digunakan, dimengerti, dan } \\
\text { dijangkau oleh semua anak }\end{array}$ \\
\hline 3 & $\begin{array}{l}\text { Tersedianya fasilitas bermain, dengan } \\
\text { minimal satu perlengkapan permainan, } \\
\text { yang aman dan tidak memungkinkan } \\
\text { terjadinya kecelakaan bagi anak }\end{array}$ \\
\hline 4 & $\begin{array}{l}\text { Menjadikan taman sebagai lingkungan yang } \\
\text { aman untuk anak bermain }\end{array}$ \\
\hline 5 & $\begin{array}{l}\text { Lokasi taman dapat ditempuh dengan } \\
\text { berjalan kaki atau bersepeda }\end{array}$ \\
\hline 6 & $\begin{array}{l}\text { Tesedianya fasilitas dan desain taman bagi } \\
\text { penyandang disabilitas agar lebih mudah } \\
\text { untuk bergerak }\end{array}$ \\
\hline 7 & $\begin{array}{l}\text { Adanya nilai daya tarik dan keindahan } \\
\text { taman bermain sehingga pengunjung } \\
\text { merasa nyaman secara visual }\end{array}$ \\
\hline 8 & $\begin{array}{l}\text { Adanya pengaturan dalam tata letak taman } \\
\text { bermain }\end{array}$ \\
\hline 9 & $\begin{array}{l}\text { Tersedianya fasilitas umum di dalam } \\
\text { maupun sekitar taman }\end{array}$ \\
\hline 10 & $\begin{array}{l}\text { Adanya keterlibatan anak dalam } \\
\text { pembangunan taman bermain }\end{array}$ \\
\hline
\end{tabular}

Sumber: Hasil Pengolahan, 2018
Prioritas ke-1 hingga ke-5 indikator kinerja taman bermain layak anak menurut persepsi anak adalah sebagai berikut:

a. Prioritas utama anak terhadap taman bermainnya adalah anak sangat menginginkan lingkungan taman bermain yang bersih dan sehat. Hal ini menunjukkan bahwa anak mengetahui risiko tidak baik apabila bermain di tempat yang kotor dan penuh sampah.

b. Anak juga sangat menginginkan tersedianya fasilitas yang beragam di taman bermain, guna menjadikan anak menggunakan waktu luangnya menjadi lebih produktif.

c. Keamanan taman bermain menjadi keinginan anak selanjutnya akan taman bermainnya. Hal tersebut diperhatikan oleh anak agar anak merasa aman dalam bermain dan tidak menyebabkan kecelakaan akibat bermain.

d. Selain itu, anak juga menginginkan taman bermain berada di lokasi yang terjangkau bagi anak agar anak dapat pergi ke taman bermain dengan mudah dan pada waktu kapan saja, mengingat bermain merupakan hal yang sangat disukai oleh anak.

Berdasarkan hasil kuesioner, indikator kinerja ke-6 hingga ke-10 dianggap bukan menjadi prioritas anak dalam memilih taman bermainnya. 
a. Anak hanya memilih taman bermain yang menyediakan fasilitas dan desain taman bagi penyandang disabilitas sebagai prioritas keenam. Walaupun bukan merupakan indikator yang menjadi prioritas anak, akan tetapi hal ini menunjukkan bahwa anak-anak juga memiliki kepedulian terhadap temantemannya yang menyandang disabilitas.

b. Selanjutnya, anak tidak memprioritaskan taman bermain yang memiliki daya tarik dan keindahan, pengaturan dalam tata letaknya, serta tersedianya fasilitas umum di dalam maupun di sekitar taman. Ketiga hal tersebut tidak menjadi prioritas anak, karena anak pergi ke taman bermain untuk bermain dengan teman-temannya tanpa terlalu perduli bahwa taman bermainnya harus indah dan teratur secara estetika, serta memiliki fasilitas umum yang lengkap.

c. Anak cenderung tidak menginginkan keterlibatannya dalam pembangunan taman bermain. Hal ini disebabkan responden dalam penelitian ini adalah anak dengan usia 9-12 tahun yang masih tidak terlalu peduli dan tidak terlalu paham pentingnya partisipasi anak dalam pembangunan taman bermain.

\section{Kesimpulan}

Jika melihat prioritas ke-1 hingga ke-5 terhadap indikator kinerja prioritas taman bermain layak anak, maka taman bermain yang memiliki fasilitas beragam; lingkungan yang bersih, sehat, dan aman; serta lokasi taman yang terjangkau menjadi prioritas teratas menurut persepsi anak. Kemudian, walaupun bukan merupakan prioritas, anak cukup menginginkan adanya fasilitas dan desain taman bagi penyandang disabilitas; taman bermain yang memiliki keindahan, keteraturan, dan kelengkapan fasilitas umum; serta terlibat dalam pembangunan taman bermain sebagaimana menjadi prioritas ke- 6 hingga ke-10. Dalam merencanakan Taman Anak Cerdas di Kota Surakarta ke depannya, hasil kajian indikaltor kinerja prioritas ini diharapkan dapat membantu pemerintah Kota Surakarta dalam membangun Taman Anak Cerdas yang berfokus pada kebutuhan sekaligus keinginan anak sebagai pengguna, secara khusus, seta menjadi masukan bagi pemerintah kabupaten dan kota lainnya untuk mengembangkan taman bermain anak guna mendukung pengembangan Kota/ Kabupaten Layak Anak.

\section{Daftar Pustaka}

Alodia, Callista dan Agus Karya. 2014. Sarana Bermain Edukatif dengan Penerapan Prinsip Pengenalan Waktu bagi Anak-anak Usia Pra Sekolah. Jurnal Tingkat Sarjana Senirupa dan Desain (1):1-8. http://jurnals1.fsrd.itb.ac.id/index.php/product/article/ download/275/243. 7 Maret 2018.

Arikunto, Suharsimi. 2013. Prosedur Penelitian: Suatu Pendekatan Praktik. Edisi Revisi 2010. Cetakan Kelimabelas. Jakarta: Rineka Cipta.

Badan Pusat Statistik Kota Surakarta. 2017. Kota Surakarta dalam Angka 2017. Surakarta: BPS Kota Surakarta. https://surakartakota.bps.go.id/publicatio n/2017/08/16/c70e0b4 680351cc99 240cbfa/kota-surakarta-dalam-angka2017.html. 17 Mei 2018.

Hadi, Sutrisno. 2016. Metodologi Riset. Cetakan Kedua. Yogyakarta: Pustaka Pelajar.

Joga, Nirwono dan Yori Antar. 2007. Komedi Lenong Satire Ruang Terbuka Hijau. Cetakan Pertama. Jakarta: PT Gramedia Pustaka Utama.

Patilima, Hamid, Marini Widowati, dan Riela Provi Drianda. 2014. Visi Kabupaten Kota Layak Anak. Pena Nusantara.

$\begin{array}{llr}\text { Peraturan } & \text { Menteri } & \text { Negara } \\ \text { Pemberdayaan } & \text { Perempuan } & \text { dan }\end{array}$ Perlindungan Anak Republik Indonesia Nomor 12 Tahun 2011. Indikator Kabupaten/Kota Layak Anak. 23 Desember 2011. Berita Negara Republik Indonesia Tahun 2012 Nomor 169. Jakarta. $\quad$ http://www.kla.id/wpcontent/uploads/2017/05/permen-12-thn2011-indikator-KLA.pdf. 16 September 2017.

Peraturan Walikota Surakarta Nomor 6 Tahun 2008. Petunjuk Pelaksanaan Taman Anak Cerdas (TAC) Kota Surakarta. 1 Juli 2008. Berita Daerah Kota Surakarta Tahun 2008 Nomor 11. Surakarta. 
Pontoh, Nia K., Delik Hudalah, Petrus N. Indradjati, dan Dimitra Viantari. 2013. Dasar-Dasar Survei untuk Perencanaan Wilayah dan Kota. Cetakan Pertama. Bandung: Penerbit ITB.

Pramudya, YB Willy. 2017. Kemen-PPPA: Hingga HAN 2017, Belum Ada Satu pun Kabupaten/Kota Layak Anak. http://wartakota.tribunnews.com/2017/07/ 23/kemen-pppa-hingga-han-2017indonesia-belum-punya-satu-punkabupatenkota-yang-layak-anak. 19 Mei 2018.

Samonsky, Ella. 2007. Space to Play in Beyoglu, Istanbul. Thesis. Cincinnati: School of Planning, College of Design, Architecture, Art, and Planning, University of Cincinnati.

https://etd.ohiolink.edu/pg 10?0::NO:10: P10 ACCESSION NUM:ucin117950300 1.9 Mei 2018.

Sari, Maylinda Permata. 2011. Identifikasi Kebutuhan Taman Bermain Publik di Permukiman Padat Perkotan Sebagai Tempat Bermain Anak-Anak. Tesis. Bandung: Program Magister Perencanaan Wilayah dan Kota, Sekolah Arsitektur, Perencanaan dan Pengembangan Kebijakan, Institut Teknologi Bandung.
Satori, Djam'an dan Aan Komariah. 2011. Metodologi Penelitian Kualitatif. Cetakan Ketiga. Bandung: Alfabeta.

Siyoto, Sandu dan Ali Sodik. 2015. Dasar Metodologi Penelitian. Cetakan Pertama. Yogyakarta: Literasi Media Publishing. http://stikesstrada.ac.id/omp/

index.php/ebook/catalog/view/3/3/10-1. 23 Juni 2018.

Sugiyono. 2016. Metode Penelitian Kombinasi (Mixed Methods). Cetakan Kedelapan. Bandung: Alfabeta.

Utami, Rina. 2014. Taman Cerdas sebagai Simbolisasi Kota Layak Anak di Kota Surakarta (Studi Kasus di Kelurahan Kadipiro Kecamatan Banjarsari Kota Surakarta. SOSIALITAS: Jurnal Imiah Pendidikan Sosiologi-Antropologi 4(1). http://jurnal.fkip.uns.ac.id/index.php/sosa nt/article/view/4032. 13 Desember 2017.

UNICEF. 2004. Building Child Friendly Cities: A Framework for Action. Florence: UNICEF Innocenti Research Centre. https://www.unicefirc.org/publications/pdf/cfc-frameworkeng.pdf. 31 Januari 2018. 